\title{
Отрывок воспоминаний бывшего командира 1-го Гомельского Коммунистического Пролетарского батальона В.С. Селиванова
}

\begin{abstract}
A втор публикуемых воспоминаний Василий Степанович Селиванов - деятель советской номенклатуры 1920-30-х годов. Однако его личный и карьерный путь оказался довольно сложным и в чем-то типичным для поколения белорусских политиков начала XX ст., которые искали альтернативы социального и национального будущего края.
\end{abstract}

В.С. Селиванов родился в 1889 г. в Могилевской губернии, в крестьянской семье среднего достатка, о чем свидетельствует его обучение в Могилевской гимназии, где он закончил 6 классов. В революционнонеспокойном для Российской империи 1905 г. Василий Селиванов уже оказался в Киеве, где начал работать на сахарном заводе и вскоре сблизился с местной эсеровской группой. Идеология Партии социалистовреволюционеров (ПСР), апеллировавшей не только к пролетариату, а ко «всему трудовому народу», а прежде всего - крестьянству, оказалась близка и наиболее понятна выходцу из белорусской деревни. В 1907 г. В. Селиванов вступает в ПСР и активно включается в деятельность ее киевской организации.

В 1907 г. за участие в заводской забастовке В. Селиванов был арестован и осужден на полтора месяца тюремного заключения с последующей высылкой на принудительные работы. Освободившись, он отправился в Германию и Польшу, весь 1911 г. проработал на одном из предприятий Познани. Затем вернулся в Киев, где его застало начало Первой мировой войны. В 1915 г. В. Селиванов был призван 
в действующую армию и попал на Западный фронт рядовым артиллерийской батареи. В 1916 г. он участвовал в крупнейшей операции русской армии под Барановичами ${ }^{1}$, которая закончилась неудачей и окончательно разложила и революционизировала солдат фронта. Власть в военных частях стала переходить к солдатским комитетам, которые больше занимались политической деятельностью, чем военным делом. Как посланец полкового солдатского комитета в дни Февральской революции В. Селиванов попадает в Петроград в руководящие структуры Партии социалистов-революционеров, примыкает к ее левому крылу.

В мае 1917 г. эсеры инициируют созыв в Петрограде Всероссийского съезда Советов крестьянских депутатов, который рассмотрел тактику партии в отношении войны и разработал аграрную программу, смысл которой заключался в лозунге «Земля - крестьянам!». В. Селиванов работал в избранном съездом Исполкоме Всероссийского совета крестьянских депутатов. Отметим, что в работе съезда и его структур принимали участие такие личности, как Владимир Ленин, Лев Троцкий, Мария Спиридонова, Виктор Чернов, Михаил Фрунзе, будущий социолог с мировым именем Питирим Сорокин. Взаимодействовать со многими из них довелось В. Селиванову.

В октябре 1917 г. произошел раскол партии эсеров: ее левое крыло пошло на союз с большевиками и приняло участие в октябрьском вооружённом перевороте. Эта часть во главе с М. Спиридоновой поддержала большевиков на II Всероссийском съезде Советов 25-27 октября 1917 г., голосовала за его решения и направила своих депутатов в высший законодательный орган революционной России - Всероссийский центральный исполнительный комитет (ВЦИК). Среди немногих эсеров в первых трех составах ВЦИК оказался В. Селиванов. Он работал в крестьянской секции и своей подписью скрепил один из важнейших законов советской власти - о социализации земли.

В. Селиванов оказывается в самом эпицентре политической борьбы за власть в стране. Левые эсеры, к которым он принадлежал, пользовались громадной популярность и оспаривали претензии большевиков на единовластие. Борьба разгорелась в ноябре-декабре 1917 г. на Чрезвычайном и Втором Всероссийских съездах крестьянских депутатов. Оба съезда поддержали эсеровские резолюции и вынудили большевиков

\footnotetext{
' Государственный архив Гомельской области (ГАГО), ф. 100. оп. 1, д. 462, л. 11.
} 
пойти на уступки. В. Селиванов был избран уже полноправным членом Исполкома Всероссийского Совета крестьянских депутатов, в который вошло всего около ста человек.

В Петрограде тогда произошла встреча, которая определила один из важнейших эпизодов в биографии В. Селиванова. Во время работы Чрезвычайного крестьянского съезда в конце ноября 1917 г. при Всероссийском совете крестьянских депутатов был создан Белорусский областной комитет (БОК). Во главе этой структуры стоял земляк В. Селиванова, уроженец Речицкого уезда Евсей Канчер. В БОК вошли делегаты-белорусы от губерний и фронтов. Комитет стремился к лидерству в белорусском движении и хотел перехватить инициативы Великой белорусской рады в борьбе за самоопределение Беларуси. БОК предложил вариант автономии Беларуси в составе РСФСР.

Можем предполагать, что в конце 1917 г. в самосознании В. Селиванова происходил процесс, захвативший многих его земляков эволюция к белорусской самоидентификации. Он самым активным образом включается в работу БОК по «организации политического устройства Белоруссии». Когда комитет добился создания при Наркомате национальностей РСФСР Белорусского отдела, в него вошли только два человека - близкий к М. Фрунзе заместитель председателя БОК Филипп Короткевич и Василий Селиванов².

Главным делом БОК стала подготовка созыва в Минске Всебелорусского съезда для легитимизации разработанных комитетом решений. Именно БОК смог переубедить высшее большевистское руководство в необходимости созыва съезда и его финансировании. Деятельность в БОК и на Всебелорусском съезде, возможно, была для В. Селиванова моментом наибольшего раскрытия его политических способностей. Е. Канчер в беседе со И. Сталиным о составе и потенциале БОК назвал В. Селиванова «замечательным самородком» ${ }^{3}$.

Съезд открылся в Минске 15 декабря. Но его работа была прервана большевиками. После съезда произошло окончательное разделение национально-демократического и просоветского крыла белорусского движения. Очевидно, для В. Селиванова классово-социалистические ценности возобладали над национальными. В начале 1918 г. он воз-

\footnotetext{
2 В. Скалабан, Яўсей Канчар - палітык, гісторык, мемуарыст, „Беларуская думка”, 2010, № 1, c. 94.

${ }^{3}$ Ibidem, c. 96.
} 
главил Смоленскую губернскую организацию Партии левых эсеров и начал активно работать в советских структурах: был избран на самый высокий пост в региональной советской иерархии - председателя Могилевского губернского исполкома.

Пойдя на союз с большевиками, левые эсеры все более расходились с ними в основных политических вопросах: отвергали необходимость «диктатуры пролетариата», заключение мира с Германией, оспаривали аграрную политику. Они высказались против подписания Брестского мира с Германией, а затем, на IV Чрезвычайном съезде Советов в марте 1918 г. - и против его ратификации. В знак протеста эсеры вышли из советского правительства и объявили о расторжении соглашения с большевиками.

В июне 1918 г. III съезд партии постановил использовать все средства для того, чтобы «выпрямить линию советской политики». В июле 1918 г. эсеры приступили к активным действиям, которые должны были спровоцировать общероссийское антибольшевистское восстание.

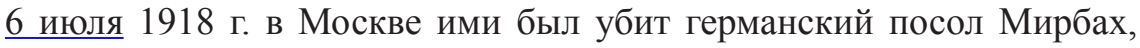
а в Симбирске поднял мятеж командующий Восточным фронтом Красной армии левый эсер М. Муравьев. Но попытка восстания в Москве провалилась, и партия левых эсеров была объявлена большевиками вне закона, начались массовые аресты эсеровских активистов по всей стране.

В. Селиванов был арестован в составе делегатов V съезда Советов, но вскоре, как и все они, выпущен ${ }^{4}$. Но по возвращении в Могилев он был арестован вновь с предписанием направления в Москву в распоряжение Всероссийской ЧК. Тем не менее, следствие было проведено на месте и Военно-революционный Трибунал оправдал В. Селиванова ${ }^{5}$, хотя окончательное обвинение было снято с него только в мае 1919 г. после нахождения на советско-польском фронте

В середине октября 1918 г. В. Селиванов оказался в Гомеле, который после срыва Брестских переговоров был занят немецкими войсками. Гомельские большевистские деятели во главе с М. Хатаевичем спешно покинули город и В. Селиванов возглавил созданный подпольно Го-

${ }^{4}$ Российский государственный архив политической истории, ф. 17, оп. 84, д. 17, л. 70,70 об.

5 ГАГО, ф. 100, оп. 1, д. 462, л. 23.

${ }^{6}$ Государственный архив общественных объединений Гомельской области, ф. 1, оп. 3 , т. 4, д. 105 , л. 1. 
мельский «революционный комитет». В январе 1919 г. из Гомеля эвакуировались немецкие формирования и В. Селиванов участвовал в восстановлении здесь большевистской власти. Только тогда он официально вступил в РКП(б).

В феврале 1919 г. Гомель и уезд вновь приобрели статус прифронтовой зоны в условиях концентрации на Полесье петлюровских и польских войск. В городе было сконцентрировано около 10 тыс. красноармейцев. В 20-х числах марта в Гомеле вспыхнуло антисоветское восстание. Основные его силы составили 67-й и 68-й полки 2-й бригады 8-й стрелковой дивизии Красной Армии, переброшенные в Гомель для прикрытия польско-петлюровского фронта. Причинами выступления красноармейцев стали их антибольшевистские настроения, неподготовленность к военным действиям, общие неудачи на фронтах, а также контакты с местным населением, недовольным «продовольственной диктатурой» и мобилизациями. Мятеж начался в ночь на 23 марта под Калинковичами. Потерпев поражение в первом же бою против отделов Северной группы украинской армии, полки оставили фронт и вернулись в Гомель, который на три дня оказался в их полной власти.

Гомельский большевистский исполком забаррикадировался в гостинице «Савой», ожидая подхода верных советской власти красноармейских частей. Однако через сутки гостиница была взята штурмом и последовала кровавая расправа над ревкомовцами. В. Селиванов принимал самое активное участие в ее организации обороны, пытался вести переговоры с повстанцами. От расправы его спасло то, что осажденный «Савой» он смог покинуть накануне ее взятия 7

После возвращения советов В. Селиванов получил пост председателя губернского продовольственного комитета новообразованной Гомельской губернии.

Однако события польско-советской войны заставили его переключиться на иную деятельность. В мае 1919 г., когда польские войска вошли в Барановичи, именно В. Селиванову было поручено формирование Первого Гомельского коммунистического пролетарского батальона. Судьбе батальона посвящены публикуемые воспоминания. Кроме важных фактов личной биографии, они интересны сведениями об эпизоде начального периода советско-польской войны на территории

7 Фонды музея Гомельского дворцово-паркового ансамбля, ф. 5, д. 5, л. 8. 
Беларуси, дают представление о степени подготовки красноармейских сил, стиле советского командования, судьбе участников красноармейских формирований.

После описанных в мемуарах событий, в декабре 1919 г. В. Селиванов был демобилизован из Красной Армии. Но в марте 1920 г. польские войска развернули второе наступление и вплотную приблизились к Гомелю. В городе было объявлено военное положение, началась срочная эвакуация губернских учреждений. В. Селиванов вновь оказался во главе городского чрезвычайного органа власти Гомельского ревкома. Через два месяца он был отправлен для организации эвакуации и обороны в отдаленную от Гомеля на 40 км Речицу, которая вскоре была взята польскими войсками. До апреля 1921 гг. В. Селиванов оставался в Речице, организовывал восстановлению города, борьбу с антибольшевистскими формированиями С. БулакБулаховича, атамана Галака, «зелеными».

В ноябре 1921 г. В. Селиванов опять избирается на должность председателя Гомельского губисполкома, но через десять дней устраняется с нее. Причины этого не известны, можно предположить, для местных коммунистов В. Селиванов так и не стал своим. Клеймо бывшего эсера так и оставалось за ним до конца жизни.

В 30-е годы В. Селиванов оказался в Москве. Политическую деятельность он прекратил и работал в органах управления торговлей Москвы. Ему удалось уцелеть в массовых репрессиях 1930-х годов, но в 1940 г. он был исключен из РКП(б) и вскоре арестован. Основанием стали “оперативные материалы” о том, что “Селиванов В.С., в прошлом эсер, на протяжении 1938-1941 гг. среди персон, которые его окружали, проводил антисоветскую агитацию и выказывал террористические настроения в отношении руководителей ВКП(б) и советского правительства"в. По этому стандартному и не требовавшему доказательств обвинению "особое совещание” при НКВД СССР 7 июня 1941 г. постановило: “Селиванава Василя Степановича за антисоветскую агитацию и террористические намерения заключить в исправительно-трудовой лагерь сроком на 8 лет".

${ }^{8}$ Государственный архив Российской Федерации. Уголовное дело № П-49383 В.С. Селиванов. Автор публикации выражает благодарность белорусскому архивисту В. Скалабану (1947-2011), предоставившему этот документ. 
Сведений о месте отбывания приговора, дальнейшей судьбе и даже дате смерти В. Селиванова в нашем распоряжении нет. 6 января 1958 г. Президиум Московского городского суда, пересмотрев дело, резюмировал: “Постановление особого совещания при НКВД СССР 7 июня 1941 г. в отношении Селиванова В.С. прекратить за недоказанностью обвинения".

Оригинал воспоминаний В. Селиванова хранится в фондах музея «Гомельский дворцово-парковый ансамбль», копия - в Государственном архиве Гомельской области. Как видно из атрибуции, написаны они были в 1933 г. в Смоленске. Мотивы и причины написания воспоминаний пока не выяснены. Возможно, их появление связано с деятельностью Гомельского музея по сбору «революционных материалов», что было устойчивой традицией советской идеологии.

Для публикации подготовлен сокращенный вариант воспоминаний. Особенностью аутентичного текста являются многочисленные отступления от грамматических и стилистических норм русского языка, что связано с низким уровнем образования автора. По этой причине некоторые фрагменты документа трудны для понимания. Поэтому при подготовке к публикации, кроме археографической обработки, проведена стилистическая и грамматическая правка, которая, однако, не нарушает содержание и смысл текста.

Автор публикации выражает благодарность сотруднику Государственного архива Гомельской области Алейниковой Марии Адольфовне за помощь в выявлении воспоминаний В. Селиванова.

Валентина Лебедева

\section{Отрывок воспоминаний бывшего командира 1-го Гомельского Коммунистического Пролетарского батальона В.С. Селиванова}

В конце марта 1919 года вооруженные до зубов белопольские офицеры и русские белогвардейцы, захватив города Вильно, Лиду и др. города, стремясь задушить власть Советов, двигались на Минск. Это наступление белополяков совпало с захватом Колчаком города Сызрань, доходя до Волги.

\footnotetext{
9 Ibidem.
} 
Осуществляя призыв партии коммунистов и по призыву Гомельского Полесского Комитета ВКП (б), мне как члену этого комитета было поручено организовать добровольный батальон для выступления на Западном фронте.

Гомель пережил 25 марта 1919 года Стрекопытовский мятеж, который, захватив власть в Гомеле, продержался у власти 3 дня, учинил еврейские погромы в Гомеле и убил лучших сынов партии - 22 комиссаров ${ }^{10}$.

Пролетариат Гомеля после этого еще больше убедился, что единственным защитником его интересов является коммунистическая партия. Это обстоятельство дало мне возможность легче и быстрее выполнить поручение Гомельского Полесского комитета партии и в двухдневный срок был организован Первый Гомельский Пролетарский Коммунистический батальон.

Лучшими моими помощниками в организации этого батальона были товарищ Хавкин М.П. - секретарь коммунистического коллектива и товарищи Раскин, Шницер, Дискант-Дарский, Алексеев и Рысин.

Во время формирования батальона вспыхнуло восстание кулацкобандитских элементов в посаде Климово бывшего Новозыбского уезда ${ }^{11}$ и по приказанию Полесского комитета большевиков, рота этого батальона под моим командованием [...] отправилась для ликвидации этого восстания.

Это кулацко-бандитское восстание явилось результатом провокации кулаков, не признающих советскую власть, которые агитировали против отправки красноармейцев на фронт против белополяков.

В двухдневный срок этой ротой батальона восстание было ликвидировано. Не было времени ожидать окончательного формирования батальона и укомплектования его командным составом. Без необходимого вооружения, продовольствия и других видов снабжения, получив знамя от Полесского комитета большевиков, батальон выступил на Западный фронт.

\footnotetext{
10 Число погибших названо Селивановым произвольно: во время мятежа погибли 11 членов Гомельского ревкома.

${ }_{11}$ Находился в 100 км от Гомеля. Сегодня - административный центр района Брянской области России.
} 
Получив в Минске распоряжение от военкома товарища Кривошеина ${ }^{12}$ о направлении в местечко Молодечно и о том, что батальон прикомандировывается к дивизии, батальон прибыл на ст[анцию]. Молодечно в распоряжение начдива 17 [дивизии].

Штаб дивизии в это время стоял в местечке Молодечно и начальником дивизии был отдан приказ о размещении батальона в здании бывш[ей] духовной семинарии и одновременно было дано распоряжение об усиленной боевой подготовке бойцов. Это последнее было весьма необходимо, ибо $30 \%$ бойцов батальона было не подготовлено к бою, а часть совершенно не имела представления об позиционной войне. Это были рабочие с фабрик и заводов Гомеля и некоторые совершенно не служили в армии.

В течение 5-7 дней усиленно занимались военной подготовкой, после чего, по приказанию начдива, батальон под моим командованием выступил на передовую позицию против белополяков в с[елах]. Забрежь и Воложино (железнодорожный блок-пост д[еревня] Листопады).

Перед отправкой на фронт комиссар дивизии Найденков ${ }^{13}$ после инструктирования меня, выдал мне бессрочную паспортную книжку на имя Сикорского Владислава Станиславовича, свидетельствующую о том, что я гражданин г. Минска. [...]

Надо отметить, что комиссар батальона Хавкин, после разговора с комиссаром дивизии Найденковым, заявил мне, что отношение к нашему батальону со стороны комиссара отрицательное и надо быть осторожным к его распоряжениям.

По приказанию комбрига, на второй день после прибытия на передовую позицию 1 рота заняла окопы Синяя Горка, 23 рота - д[еревню] Стайки и 3 рота - Листопады.

При вступлении на позицию первой роты батальона, белополяки встретили ее наступлением на занимаемые ею окопы Синяя Горка. В этом бою наступление противника было отбито, самоотверженность

12 Кривошеин Николай Иванович (1885-?) большевистский деятель Беларуси, в декабре 1917 г. - член Минского Совета рабочих и солдатских депутатов. Руководил разгоном Всебелорусского съезда. С февраля 1918 г. - член штаба Западного фронта Красной Армии.

${ }_{13}$ Найденков Григорий Павлович (?-1919) - государственный деятель Беларуси, член Временного рабоче-крестьянского советского правительства БССР (январь 1919 г.), правительства Литовско-Белорусской республики. В мае 1919 г. арестован по обвинению в злоупотреблениях, расстрелян. 
была проявлена командиром роты товарищем Хричиковым и коммунистами Рысиным, Цирлиным, Зеленковским. Мне в этом бою пришлось получить легкое ранение в руку и в этом бою мы потеряли двух товарищей.

Через 2-3 дня неприятель перебросил большие силы на участок Стайки, занимаемый второй ротой и сделал попытку пойти в наступление. Это наступление было встречено контратакой со стороны второй роты. Рота потеряла несколько убитых и раненых. [...]

После этого боя почему-то полки, занимавшие эту позицию: 5-й Минский, 3-й Седленский, 6-й Гродненский были сняты, и этот участок оставлен был на ответственности нашего батальона. В батальоне совершенно не было орудий, пулеметов, а главное батальон был без квалифицированного командного состава. Эти обстоятельства подавляюще действовали на бойцов батальона. А главное, что отражалось на настроении, это то, что, несмотря на все мои просьбы о прикомандировании к нам батареи и нескольких пулеметов и доставки патронов, все это оставалось где-то в штабах дивизии. [...]

Занимая в течении месяца этот участок фронта, батальон смог при самоотверженности коммунистов и рабочих выдержать ряд атак и потерял убитыми и раненными много товарищей.

30 июня по приказанию комбрига и при моем решительном возражении, батальон, не имея орудий, снарядов и пулеметов, при недостаточном количестве патронов вынужденно пошел в наступление на Синюю Горку и в результате этой авантюры $1 / 3$ батальона была потеряна (убиты и ранены). После боя, отступивши в местечко Воложино, по приказанию Комбрига из трех рот батальона была сформирована одна рота, которой было приказано отправиться в деревню Лесники (8-10 километров от Воложино) и занять боевой участок. К уходу роты на участок деревни Лесники на блок-пост «Забережье» прибыли вагоны с оружием, пулеметами и снарядами, но нам их получить не разрешили. [...]

2 июня, противником был занят блок-пост Забережье, были захвачены прибывшие вагоны. К вечеру 2 июня вновь сформированная рота прибыла в деревню Лесники. Высланная заранее разведка доложила, что противник расположен рядом с деревней со значительными силами, имеет два орудия и несколько пулеметов. Возвративших ночью из разведки товарищи Хавкин, Рысин и другие привели двух пленным солдат, которые рассказали мне о месте расположения противника, 
численности войск и о намерении утром сделать наступление, занять деревню Лесники и дальше двинуться по направлению к местечку Молодечно. Подтверждением этих сведений служили сообщения других товарищей, прибывающих из разведки. Утром 3 июля противник пошел в наступление и мы должны были отступить на другую позицию. Отступать без боя нам никак нельзя было, ибо мы к утру 3 июля находились в кольце противника, и рота вынуждена была идти в атаку с целью пробиться на другую позицию. К сожалению, мы оказались не подготовленными к такой атаке и 3 июля в 8-10 часов утра под деревней Лесники рота потеряла крупнейшее поражение. Большая часть была убита и ранена, явившихся жертвой пулеметных пуль, остальные бойцы были взяты в плен неприятелем.

Это поражение роты, явилось результатом неподготовленности части бойцов к такой атаке. Когда я скомандовал «в атаку!», правый фланг роты бросился со штыками против пулеметных пуль, бойцы левого фланга, перепугавшись усиленной пулеметной стрельбы неприятеля, легли, без окопов и без всяких прикрытий на открытом поле. Я бросился бежать к ним, и был ранен в ногу и лишен возможности дальше командовать. [...]

Меня раненого несколько товарищей отнесли в ближайший сарай, остригли мне волосы, это надо было потому, что белополяки знали меня, как по фамилии, так и по внешним признакам. Кроме того, сняли с меня кожаную тужурку, как одно из доказательств, изобличающих меня, как командира батальона, после оставили меня в сарае, а сами ушли.

После боя поляки учинили соответствующую фронтовую процедуру над взятыми пленными: конвой приехал к сараю на дрогах, уложили раненных на них, в том числе и меня и привезли нас на площадь, где уже были построены пленные, окруженные конвоем и готовые к отправке куда-то. Перед отправкой польский офицер, вызывая [красноармейцев] из строя поодиночке, приводил их к дрогам, на которых я лежал, и спрашивал чтобы указали: «кто ваш комиссар?». С большим удовольствием отмечаю, что те товарищи, которых вызывали уличить меня, все отвечали, что нашего командира и комиссара здесь нет, хотя все хорошо видели меня и знали в лицо. Кто-то заявил: «я сам видел, как на моих глазах наш командир был убит». После этого опроса пленных окружил военный конвой, оставив дроги с раненными позади строя, отправили нас по направлению в город Лида, где долго не при- 
шлось ожидать. Мы были посажены в товарные вагоны и отправлены в город Белосток. Раненным, как на месте ранения, и так и во время конвоирования, никакая медицинская помощь, как правило, не оказывалась. В Белостоке нас встретил пересыльный лагерь, в котором уже находились товарищи моего батальона, взятые в бою у местечка Воложино и во время наступления на Синюю Горку.

При помощи товарищей, которые давно уже находились в этом лагере, нам легко было скоро освоится с той кошмарной лагерной обстановкой, которую создали белополяки для пленных большевиков.

В этом лагере, как правило, пленным хлеб совершенно не выдавался, а о горячей пище и говорить не приходится. В этом лагере уже 8-10 дней совершенно не получали хлеба и мы явились свидетелями того, как пленные находясь в этом лагере рвали траву из-под проволочных заграждений и кушали ее.

Кроме измора голодом, на другой день после нашего прибытия, белопольские жандармы начали окончательно раздевать пленных, снимая верхнюю одежду и забирая ее. У кого было приличное нательное белье, его забирали, взамен давали грязное тряпье, которое нельзя было одевать.

Раненые продолжали не получать медицинскую помощь в лагере, были случаи, что умирали от заражения крови, а некоторые истекали кровью из ран и находились в бессознательном состоянии. В эти мучительные моменты для раненых, в значительной степени помогала Мария Ткач, работавшая в то время в Белостоке в подпольной организации, которая по целым дням простаивала около проволочных заграждений и передавала перевязочные средства (йод, бинты).

Когда отправляли нас с усиленным конвоем на вокзал Белосток, мы не знали, куда нас отправляют, и для меня была мучительной мысль, [...] что нас направляют в Брест-Литовский лагерь, а я хорошо знал, что в это время в Брест-Литовском лагере сотни пленных умирали от заболевания холерой.

Прибыв в Варшаву, пленных выстроили в ряды, раненных несли на руках здоровые пленные. Нас отправили куда-то за город в военные казармы на обед. В пути этого следования, со стороны польских белобандитов было проявлено гнусное издевательство: [...] подходя к идущим в строю пленным, толкали палками в зубы и применяли физические методы, но конвой против таких гнусных выходок польских белобандитов не возражал. 
По улицам, которыми нас вели, на тротуарах и на мостовой большое количество народа смотрели на раздетых пленных, как на зверей. В их числе были рабочие, которые, как видно было, проявляли свое негодование к буржуазии и некоторые рвались к пленным, чтобы разговаривать с ними, но конвой был строгий по отношению к рабочим и близко к пленным их не допустил. [...]

Вечером нас привели на станцию Варшава и приготовили к отправлению поездом. [...] Нас для ожидания поезда вывели на какую-то погрузочную платформу, на которой мы должны были оставаться до утра. В ту ночь, к нашему несчастью, лил проливной дождь. Можно было бы мириться с тем, что нас оставили на всю ночь стоять на ногах под дождем, но трудно было пережить экзекуции белобандитов из корпуса Галера (их называли гарельщиками). Корпус этот известный всем, который зверски относился к красным: приходили, издевались над пленными, применяли физические методы, вплоть до избиения, с насмешкой указывали на того или иного пленного говоря, что вот это тот, которого я видел в Москве в Чека.

Утром мы опять сели в товарные вагоны, в которых мы проехали города Лоздь, Калиш и, наконец, привезли нас на станцию Велково, откуда на расстоянии 2-3 км. находился концентрационный лагерь, в который были мы со станции конвоированы. В лагере около ворот простояли, выстроившись в колонну, час или два, после чего явился комендант лагеря, известный белобандит помещик Малиновский (имение его было около Баранович Минской губернии), который дал нам понять, что мы вступили в полосу самой жестокой белопольской экзекуции. Это выразилось, во-первых, в том, что всех пленных, в том числе и раненных, отправили в сарай, где была устроена мойка холодной водой. Здесь нам приказали раздеться, сдать наше барахло в дезинфекционную камеру, вместе с раненными впустили в этот сарай, после чего раздетых в течение 2-3 часов держали в этом сарае.

После этой процедуры мы были размещены в бараках большевистского лагеря, которые не были приспособлены для человеческого жилья: были одни голые нары, на которых пленные расположились. Медицинской помощи раненным и в этих бараках не оказывалось, только на четвертый день после моего пребывания, мне пришлось попасть в амбулаторию на перевязку, после чего в этот барак мне больше вернуться не пришлось. 
Находясь эти три дня в большевистском бараке, я был свидетелем того произвола, который позволял себе комендант лагеря Малиновский. Были такие случаи: входит польский жандарм в барак, случайно никто его не заметил и никто не скомандовал «смирно!». Через некоторое время является 5-6 палачей с нагайками, специально сделанными для избиения пленных коммунистов, командуется для находящихся пленным в бараке «ложись!» и начинается применение телесного наказания по методу, применяемому помещиками во времена крепостного права над крестьянами. Второй пример: входит в барак польский офицер, командует: «пленные уроженцы Могилевской губернии выходите строится». После построения в шеренгу, следует команда «ложись!».. и опять является 5-6 палачей и применяются также издевательства, что и в первом примере. И так повторялось каждый день, только не во всех бараках. [...]

Находясь в течении 3-х месяцев в бараке, у меня не выходила из головы мысль о совершении побега. Для меня не предоставляло никакой трудности расстояние свыше 1000 километров. Преодолимым делом для меня было прорезать 7 рядов проволочного заграждения. Это все для меня казалось пустяком, но меня мучила и останавливала мысль, что после моего побега пленные, находящиеся со мной в бараке, обречены на 8-дневную голодовку и применение к ним телесного наказания. Такой был порядок установлен комендантом лагеря Малиновским, что если кто-нибудь совершит побег из большевистских бараков, к пленным, находящимся в этом бараке, применяется «какрант»- не выдается в течение 8-ми дней совсем хлеб, применяются телесные наказания - избиение розгами.

В лагере в это время свирепствовало заболевание холерой и дизентерией, десятки человек ежедневно умирали и вывозились на кладбища, расположенные в черте лагеря, но в отдельности от бараков. В это время в лагере находилось пленных около 25000 человек (таковы были разговоры в лагере). Лагерь делился на 3 части. Первая - большевистские бараки, в которых были заключены исключительно красные. Вторая - лагерь интернированных петлюровских войск с командным составом, врачами и фельдшерами, т.д. И третья - отдельные бараки для интернированных поляками тульских полков ${ }^{14}$. Это те полки, кото-

14 Полки были сформированы в Тульской губернии России, поэтому за ними закрепилось неофициальное название «тульские». 
рые 25 марта 1919 года во главе с белобандитом Стрекопытовым ${ }^{15}$ захватили в Гомеле власть и после того, как они были выбиты из Гомеля, отступили по направлению Речица, Калинковичи, Мозырь, перешли демаркационную линию. Поляки, по-видимому, с ними не посчитались и также направили их в концентрационный лагерь. Все три лагеря имели свои кухни и жили в разных условиях. Пленные, находившиеся в украинском лагере, пользовались большой льготой и привилегиями, работали на полевых работах, в амбулатории, в лазарете и т.д., а врачи и даже некоторые фельдшера пользовались увольнением из лагеря в местечко Щелково. Большевистский лагерь был в совершенно особом положении и к нему применялись все методы буржуазной экзекуции. Бараки, в которых находились пленные бывших тульских полков, находились на положении чего-то среднего, но осторожность к ним и охрана применялась большая, чем к украинскому лагерю.

Находясь в госпитальном большевистском бараке, я видел, как приводили пленных из большевистских бараков, совершенно изрубленных нагайками, часть из них в течение суток умирала.

Большевистский госпитальный лагерь обслуживался врачами Лившицем и Саципионом. Это были пленные из интернированной петлюровской армии, оба уроженцы Харькова. Кроме того еще обслуживался тремя фельдшерами - Гончаровым, Горбасовым, а фамилию третьего не помню. Первые два - уроженцы Чериковского уезда бывшей Могилевской губернии. Когда приводили изрубленных пленных большевиков в госпитальный барак, доктор Саципион, а особенно Лившиц, открыто возмущались и даже помниться, что Лившиц рассказывал какому-то польскому офицеру открыто, в присутствии пленных, о тех ужасах, которые происходят в большевистских бараках. Не знаю, к какой политической партии принадлежали доктора Лившиц и Саципион, но их отношение к большевикам давало понять, что они сочувствуют советской власти. Доктор Лившиц, имея некоторую свободу отпуска из лагеря в местечко Щелково, там проводил организацию доставки хлеба в большевистские бараки. Такая доставка хлеба имела место по субботам и производилась исключительно через раввина, это проис-

15 Стрекопытов Владимир Васильевич (1890-1941), штабс-капитан российской армии, заведовал хозяйственной частью 68 полка, возглавил антибольшевистское восстание в Гомеле. 
ходило под флагом помощи пленным евреям, а их, несомненно, было много в плену.

В августе или в начале сентября месяца свирепствующая экзекуция в большевистских бараках значительно была уменьшена, главным образом было прекращено телесное наказание. Был смещен комендант лагеря Малиновский. Это произошло после того, как рабочие - депутаты Сейма приехали и обследовали бараки, узнали от пленных, как над ними издевались.

Смягчение режима в лагере не приостановило мою мысль о побеге. Об этом знали доктора Саципион и Лившиц, а также фельдшера. Я от них не скрывал своего намерения и в результате мы несколько раз вместе обсуждали план побега. Пожелали со мной вместе бежать фельдшера Горбачев, Гончаров и еще третий из дизентерийного барака [...] уроженец Сибири, служивший фельдшером в одном из тульских полков. Вопрос о побеге окончательно был решен. Чтобы облегчить побег из лагеря и освободить от наказания пленных, оставшихся в моем бараке, было решено перевести меня в дизентерийный барак, где я должен был находиться до удобного момента к побегу. Это место было самое удобное для побега, ибо там охрана была более слабая, и этот барак находился далеко на окраине всего лагеря. Фельдшерам из госпитального барака было легче готовиться к побегу, ибо они имели возможность ходить из барака в барак, в том числе и приходить в дизентерийный барак. Недели за две до побега вышеуказанные фельдшера начали ежедневно посещать дизентерийный барак, засиживались поздно вечером с целью подготовки побега.

15 октября доктор Лившиц дал нам десять марок на дорогу и сам лично купил в кантыне (лагерная лавка) три буханки хлеба, еще днем мы с ним распрощались и в 10-11 часов вечера мы вчетвером были уже по ту сторону проволочного заграждения. В ходе подготовки к побегу нас беспокоила мысль, как можно без инструмента перерезать 7 рядов проволочных заграждений (из колючей проволоки). Но во время подготовки нам удалось установить, что проволоку даже резать не следует, что ее можно вдвоем легко оторвать от столбиков, к которым она прикреплена. Этот лагерь строился еще во время империалистической войны ${ }^{16}$, по-видимому, в 1914 году и значительная часть столбов, особенно в этом месте вокруг дизентерийного барака,

\footnotetext{
16 Так большевики называли Первую мировую войну.
} 
оказались подгнившими и отрывать проволоку, особенно нижние ряды, не составляло больших трудностей. Путем отрывания от столбиков проволоки, нам легко удалось в течение нескольких минут преодолеть эти препятствия.

План побега был рассчитан до советской границы - за месяц, идти мы должны были по ночам, отдыхать должны были днем в помещичьих стогах на полях, идти должны были по полю, близко около Екатерининского шоссе (шляха), ведущего через город Кутно, Варшаву, Белосток, Минск. Рассказывали нам в лагере, что по этому шляху когда-то Екатерина Великая проезжала и поэтому его так называют в Польше (Екатерининский шлях). Должны были на лодках переехать реку в городе Кутно (кажется, и река называется Кутно), переехать около Варшавы реку Вислу на лодках и, если денег не будет на переезд, то достать где-либо на берегу лодку и переправиться на тот берег самим.

Нам казалось, что пройдя Варшаву, мы [будем] уже на территории Советского Союза. В первую ночь нашего побега, мы потерпели большую неудачу. Нам казалось, что с целью отвлечь внимание нужно сделать значительный круг, километров 10-15, и потом выйти на Екатерининский шлях. В этом обходе мы попали в болотистое торфяное место, где во время добычи торфа остались глубокие ямы, которые были наполнены дождевой водой, и мы, хорошо искупавшись в этих ямах, погрязли окончательно в болоте. Выбравшись с трудом из этого болота к утру, мы отошли от лагеря километров 20-35, сделав дневку в одном из стогов соломы от обмолоченной ржи или пшеницы.

Надо сказать, что первый день, без привычки, промокши в воде до костей, в болотистой грязи, было трудно пролежать день, мне лично казался этот день целой вечностью. В третью ночь нашего побега мы подошли к городу Кутно. Долгие поиски на берегу реки лодки для переправы через реку не увенчались успехом и мы уставшие решили оставаться дневать в хлеву на чердаке у одного из польских домов, не переезжая реку Кутно. За трое суток мучительного похода у товарища Горбачева поколебалась вера в то, что мы можем перебраться в таких мучительных условиях свыше 1000 км. и он решил вернуться обратно в лагерь, даже не считаясь с тем, что его там ожидает, но он решил, какие бы его экзекуции не ожидали, он вернется обратно и будет находится в лагере до тех пор, пока его в законном порядке не освободят. Распростившись в эту ночь с нами, под утро товарищ 
Горбачев отправился обратно по тому же Екатерининскому шляху в лагерь Щелково. День мы лежали на чердаке хлева, первый раз за трое суток с лишним, мы хотели покушать имеющийся у нас хлеб, но, увы, этот хлеб оказался настолько размокшим и помятым за время нашего похода, что кушать его было невозможно, но он являлся нашей единственной пищей.

К вечеру этого дня у меня температура повысилась, вероятно, до 40 градусов - так определили мои фельдшера, и я оказался совершенно в бессильном положении и не только двигаться дальше в путь, но даже подняться не мог. Мои спутники в испуге суетились и не знали, что делать. После долгих рассуждений мы решили, что я остаюсь один больной в сарае, вызываю хозяина, чтобы меня забрали и лечили, а мои спутники вдвоем продолжат путь побега. Товарищи долго не соглашались, очень не хотели меня оставить, но, по моему настоянию, они согласились идти вдвоем, оставив меня одного.

Вечером, распростившись с товарищами, мы разделили 10 марок пополам, разделили остаток хлеба, товарищи направились в путь, а я остался в сарае. Пролежал ночь, а потом, уснув, укрывшись соломой, и проспал, по-видимому, целый день. Проснулся ночью - в котором часу, какого числа и какой день был, конечно, ничего не помню. Одумавшись после сна, решил спуститься с чердака и отправиться в город и, если у меня не будет сил, самому явится в варту (польская полиция). К сожалению, когда я подошел к двери, где стояла лестница, по которой мы поднимались на чердак, ее на месте не оказалось - какая-то злая рука перенесла ее в другое место. Сообразивши, что у меня есть на ногах обмотки, которыми у меня были обмотаны ноги, приспособив их вместо веревки, без больших затруднений, я был на земле. Решил никаких обходов моста через реку Кутно не делать, хотя мне казалось, что часовой охраняет мост [...] и он освещался яркими фонарями. Вообще решил ни от кого не прятаться, а идти напролом. [...] Ночью перешел я весь город Кутно, почувствовав себя более крепким, ни одна душа меня в городе не встретила. Я избрал по городу направление идти по линии телеграфных, телефонных столбов, где наибольшее количество проводов, знал, что эта линия меня выведет на тот же Екатерининский шлях. [...] Я решил все же до Варшавы совершать поход ночью, если удачно пройду Варшаву, то себе позволю дневное путешествие.

Не помню, сколько я шел до Варшавы, но, во всяком случае, больше недели. Подходя к Варшаве, у выходных стрелок железнодорожного 
пути мне пришлось подойти к стрелочнику, расспросить его, как можно ближе и легче перейти Варшаву. Рассказал ему, что я германский пленный и что я находился три года в германском плену, взят во время империалистической войны, и что теперь решил пробираться пешком на родину. Этот план для меня был осуществлен. Стрелочник оказался служившим на железной дороге в городе Минске (кажется, на ЛибавоРоменской станции), легко с ним было договориться на русском языке, он охотно мне поверил. Кроме того, он сжалился надо мной и предложил мне, чтобы я посидел в будке часа полтора - до 6 часов вечера, а потом он сменяется и что он возьмет меня с собой домой и я у него переночую и завтра он меня препроводит через г. Варшаву. Между прочим, он меня очень просил, что, когда я проберусь в г. Минск, чтобы я отыскал его сына, который служит в каком-то полку, записал мне его фамилию и номер полка. [...]

Назавтра около 2 часов дня после того, как этот рабочий отдохнул, он мне купил хлеба, и мы вместе с ним пешком отправились на другую сторону города Варшава по направлению к шоссе, ведущему на город Белосток. Переход через Варшаву мы совершили за 2-3 часа, и к вечеру я уже был вместе с этим рабочим на белостокском шоссе. Минувши самую грозную опасность - переход через Варшаву, я решил в дальнейшем идти, как удобнее - днем или ночью, вернее тогда, когда позволят мне силы.

С этим решением я в течение 7 дней, идя, когда днем когда ночью, пришел в Белосток и потом дальше через города Слоним, Волковыск, через бывшие Скобелевские лагеря ${ }^{17}$ и дальше по направлению на город Речицу через пинские болота.

Когда я подошел к границе, был уже ноябрь месяц, были уже снега, и мне в моем летнем платье было путешествовать не так уж приятно. Единственное, что меня поддерживало, это помощь со стороны беднейшего крестьянства в деревнях Минской, Слонимской губерний, которые снабжали меня обувью (лаптями) и давали кушать. При выборе места, куда зайти отдохнуть, мною выбирались в деревнях дворы самые беднейшие, я рассчитывал (и в этом расчете не ошибался), что эти люди

17 «Сколебелевские лагеря»-военные учебно-тренировочные лагеря, построенные в конце 19 века под Барановичами и названные в память российского генерала М. Скобелева, который в 1882 г. находился в Минске со штабом 4го корпуса российской армии. 
меня не выдадут и поддержат. Как правило, везде я рассказывал, что я сидел в германском плену, попал я в плен еще в 1915 г. и прибавлял к этому, что мне надоели всякие издевательства германского офицерства и жандармерии и я решил дальше этого не терпеть и пробраться пешком в Россию. Кроме этого, был такой случай в деревне около города Слонима. В одной бедной семье, в которой был один рабочий, работавший на шахте, я ему рассказал, кто я такой, где я был в плену и каким путем я пробрался в Советский Союз. Он сделал все, от него зависящее, вплоть до того, что послал своего отца - старика провожать меня до следующей деревни на расстоянии 30 км.

Второй раз, где мне пришлось признаться, кто я такой одному рабочему, живущему в деревне, расположенной в 4-5 километрах от позиции, которая занималась поляками. Это признание мною было сделано вынужденно, ибо я попал в безвыходное положение. Дело было так: на расстоянии 20 км от передовой позиции в одной из деревень женщина, к которой я зашел обогреться, рассказала мне путь, как я могу пройти более безболезненно через позиции, занимаемые поляками. Я рассчитал, что выйдя в 5-6 часов вечера (а это уже были сумерки), смогу к утру пробраться через передовые позиции и быть уже на территории Советского Союза.

К сожалению, в эту ночь я сбился с пути, а в эту ночь свирепствовал сильный буран. Я в течение целой ночи бродил по глубоким снегам наощупь. Только на утро я наткнулся на какую-то деревню и решил зайти в первый дом узнать, где я нахожусь. К сожалению, хозяин этого дома, увидев меня, свирепо заявил: «Немедленно отсюда уходите, ибо у нас есть приказ, если кто-нибудь чужой зайдет, немедленно направлять его в штаб, а в противном случае мы несем ответственность по условиям военного времени». И дальше он заявляет: «От этой деревни позиции в 3-4 км, здесь расположены польские войска (драгуны), уходите как можно скорее». [...] Метель в это время свирепствовала, и я решил зайти еще в какую-нибудь самую разваленную халупу в деревне, зная, что в таких местах едва ли будут помещаться польские солдаты, чтобы узнать более точно, что мне дальше делать.

План этот для меня удался с большой исключительностью. Переходя на другую сторону деревни, на окраине я зашел в одну из самых полуразрушенных хижин, где меня встретил рабочий, которому я был вынужден рассказать, кто я такой, откуда и куда направляюсь. Его такое сообщение не удивило, и он заявил мне: «Для меня ты сообщил не 
большую новость. За последний месяц я уже перевел десятки коммунистов на ту сторону позиций, и все было благополучно. Так я сделаю и с тобой». Он мне предложил, чтобы я улегся на печи и лежал целый день до сумерек, и вечером мы вместе пойдем через позиции. Между прочим, в разговорах он мне сказал: «Я тебя помню, когда мы были вместе на Белорусском съезде в Минске в 1918 году ${ }^{18}$, когда большевики разогнали эсеровский съезд, созванный белорусской радой ${ }^{19}-$ Сикорским ${ }^{20}$, Канчером $^{21}$, Мамонько ${ }^{22}$ и др. Я хорошо помню, как ты выступал на этом съезде». [...]

Часов в 4-5 дня мы вдвоем направились через лес по направлению к реке Птичь, на берегу которой была позиция белополяков, а по ту сторону реки уже была позиция красных. Повторяю, расстояние это было всего 4-5 км. Глубина снега, продолжающаяся метель и абсолютное бездорожье заставило двигаться до позиции 4-5 часов. Нас задерживало при переходе то, что я был совершенно выбившись из сил и едва мог двигаться.

Мы заблудились, и этому товарищу пришлось зайти в один дом к живущему в нем поляку и выяснить, как удобнее пройти к позиции. На мой вопрос, как он может разговаривать с хозяином на такую тему, этот рабочий мне сказал, что я когда перевожу людей через позицию, рассказываю, что я перевожу переселенцев из Слонимской или Гродненской губернии, семьи которых живут на территории Советского Союза, и что мужчины ездили на родину осенью засевать поля, а теперь идут с тем, чтобы добиваться разрешения о переводе семейств на родину.

Узнавши о месте перехода через позицию, нам удалось без больших затруднений перейти реку Птичь и попасть на переднюю позицию, занимаемую красными. Дальше нас отправили в караульное помещение (не помню какого батальона). Потом ночью, по распоряжению

18 Дата указана ошибочно, съезд состоялся в декабре 1917 г.

19 Великая Белорусская рада - руководящий центр белорусского национального движения с осени 1917 г., главный инициатор созыва Всебелорусского съезда.

${ }^{20}$ Известия о таком участнике белорусского движения не найдены.

${ }^{21}$ Евсей Канчер не входил в Великую белорусскую раду. Созданный им Белорусский областной комитет при Всероссийском крестьянском съезде был оппонентом рады в вопросе о независимости белорусской государственности.

${ }_{22}$ Мамонько Иосиф Алексеевич (1889-1937), деятель белорусского движения, член Великой белорусской рады, один из организаторов Всебелорусского съезда, член ЦК Партии белорусский эсеров. 
командира батальона, отправили нас на квартиру в деревню, в которой в течение суток я отдохнул, потом он сделал распоряжение отвести меня на ст[анцию] Калинковичи, километров в 40 от этой деревни, где был расположен батальон. Подробно командир батальона выяснил место расположения поляков, численность войск и т.д.

Таково краткое путешествие пешком из польского плена на протяжении 1000 км. от местечка Щелково до Гомеля, которое заняло время 5 недель. Вышел я из лагеря 15 октября 1919 года и в Гомель прибыл 13 ноября 1919 года.

август 1933 г.г. Смоленск Член партии ВКП(б) с 1/1-1919 г., Красный партизан В. СЕЛИВАНОВ

\section{Fragment wspomnień W. S. Seliwanowa, dowódcy 1. Homelskiego} Komunistycznego Proletariackiego Batalionu (streszczenie)

Wspomnienia bolszewickiego komisarza batalionu Armii Czerwonej są poświęcone pierwszemu etapowi wojny polsko-bolszewickiej na terytorium Białorusi. Na przykładzie jednego batalionu pokazano warunki powstawania i poziom gotowości bojowej jednostek Armii Czerwonej, a także przyczyny ich porażki. Została ukazana opieka nad pojmanymi w niewolę żołnierzami Armii Czerwonej w obozie Strzałkowo i historia ucieczki z niego autora.

\section{Fragment of memories of $1^{\text {st }}$ Homel Communist Proletarian Battalion commander W. S. Selivano (summary)}

Bolshevic commissar's memories of the Red Army battalion are devoted to the episode of the initial stage in the Soviet-Polish war in the territory of Belarus. On an example of one battalion the conditions of formation and the level of combat readiness of the Red Army units, the reasons for their defeat are shown. The circumstances of the Red Army captive soldiers' custody in the camp Schelkovo, the history of the author's escape from it are disclosed. 